\title{
Broadening Nigeria's Revenue Base: Exploring Blue Economy Activities
}

\author{
Abubakar Umar Farouk ${ }^{1}$, Rabiu Saminu Jibri2 ${ }^{2 \& 4}$, Zaharaddeen Salisu Maigoshi ${ }^{2}$, Tijjani Habibu Ahamad ${ }^{3 \& 5} \&$ Muktar \\ Musa Bako² \\ ${ }^{1}$ Department of Accounting, Yusuf Maitama Sule University, Kano, Nigeria \\ ${ }^{2}$ Department of Accounting, Bayero University Kano, Nigeria \\ ${ }^{3}$ Department of Accounting, Ahmadu Bello University Zaria, Kaduna, Nigeria \\ ${ }^{4}$ Department of Accountancy, Kano State Polytechnic Kano, Nigeria \\ ${ }^{5}$ Department of Accountancy, Hussaini Adamu Federal Polytechnic Kazaure, Jigawa, Nigeria \\ Correspondence: Rabiu Saminu Jibril, Department of Accounting, Bayero University Kano, Nigeria.
}

Received: March 25, 2021

Accepted: April 2, 2021

Available online: April 26, 2021

doi:10.11114/afa.v7i2.5244

URL: https://doi.org/10.11114/afa.v7i2.5244

\begin{abstract}
The study explores appropriate mechanism for diversifying Nigeria's revenue to tap from the opportunities offered by the blue economy. The study conceptually reviewed extant literature as a basis for acquiring an in depth understanding of the phenomenon with a view to offer practical recommendations on the issue. The study discovered that blue economy has the potential of augmenting government revenue if the financial and environmental issues bedeviling the development of the sector are properly addressed. Thus, the study recommends political will and strong institutions for effective running and implementation of blue economy strategies in the nation based on the existing international standards. It also suggested that, to boost revenue from blue economy, Area-based Management needs to be established.
\end{abstract}

Keywords: Revenue, Exploring, blue economy

\section{Introduction}

Nigeria is losing colossal revenue from blue economy due to the inability of the country to efficiently utilize the opportunities presented by the sector (Alongi \& Carbon, 2018). Although, the country is blessed with a coastline of about $870 \mathrm{~km}$ and about 3,000 kilometers of inland waterways with varieties of natural resources, the volatile and ruthless implications of over-dependence on oil, has further necessitated the need to diversify the Nigerian economy from oil towards the trend of the blue economy.

The Blue Economy is a new realm of evolving economic activities consolidating the great opportunities offered by oceans and seas. Blue Economy is an ocean-based counterpart to the green economy designed to advance human welfare and social equity while achieving environmentally sustainable economic growth of a nation. The term 'Blue Economy' is increasingly gaining popularity, which was influenced at Rio +20 conference that first emerged during the 2012 United Nations Convention on Sustainable Development (UNCSD). In other words, blue economy is envisaged as an assimilation of short and long term economic activities and development based on social and financial inclusion, environmental sustainability and innovations evaluated and determined on and around the sea (Amusan \& Akinyemi, 2019; Voyer, Farmery, Kajlich, Vachette, \& Quirk, 2020).

The global society is prospecting more towards the seas and oceans for economic wealth., it is forecasted that the annual economic value of maritime-related activities will reach 2.5 trillion Euros per year by end 2020, therefore, world's oceans, seas and rivers are the major source of wealth, creating trillions of dollars' worth in goods and services as well as employing billions of people (Garland, Axon, Morrissey, Graziano, \& Heidkamp, 2019). For instance, based on the statement issued by Economist Intelligence Unit report (EIU, 2015), China's sea economy contributed \$962 billion or 10 per cent of GDP in 2014 employing 9 million people. Similarly the United States valued its sea economy at $\$ 373$ billion in 2018 or 1.8 per cent of the gross domestic product.

In Nigeria, the volatile and ruthless implications of over-dependence on oil, coupled with the interruption upon global markets by COVID-19 and multiple constraining factors like the oil price crash, has far reaching consequences for the economy. Moreover, Nigeria has inadequate data management and lacks capacity building which leads to deficient 
knowledge and competence on the proposed agenda. This and other reasons cultivated the need to diversify the Nigerian economy from oil towards other areas such as the blue economy to boost its revenue. The blue economy has the potential of augmenting government revenue if the financial and environmental issues bedeviling the development of the sector are properly addressed.

The 2020 national budget of N10.59 trillion ( $\$ 29.42$ billion) assumed an average price of oil at $\$ 57$ per barrel and production is expected to range between 1.7 million and 2 million barrels per day. That was not a bad projection although, on the face of it, the oil price benchmark appeared very ambitious. With the unforeseen changes in the nations` economy it is highly important for the country to embark upon different economy strategies for generating more revenue. Of course the nation stands to gain immensely if it adopts and implements a credible strategy for harnessing the resources of the blue economy considering that the country is strategically located within the resource-rich Gulf of Guinea (Cavaleri, Martins, Andrade, Ribeiro, \& Turra, 2020; Katila, Ala-rämi, Repka, Rendon, \& Törrönen, 2019; Ocean \& Biologically, 2018; Folami, 2017).

Hence the need for the country to diversify its economy is becoming inevitable. The diversification to blue economy has the capacity to save the country against post COVID-19 unforeseeable revenue negative impacts when the opportunities under it are competently and successfully utilized. Accordingly, the main aim of this study is to explore appropriate mechanism for diversifying Nigeria's revenue to tap from the opportunities offered by blue economy. The study is literature based. Its main objective is to explore the diversification of Nigeria's capacity to broaden its revenue generation base with particular reference to the emerging but yet untapped economy. It is divided into five sections. This section which is on the introduction and warming up of the study is followed by section two literature review that contains critical review of relevant works on the area of the study. Section three is on methodology and prepositions while section four is on summary and conclusion. The last section is section five on recommendations.

\section{Literature review}

\subsection{Blue Economy}

The blue economy refers to the utilization of oceans, seas, and coastal resources for sustainable economic development through ecosystem integrity (WWF, 2018). The blue economy gives series of opportunities for revenue generation, economic growth, clean, sustainable, and reasonable blue growth in traditional and emerging sectors ((EIU, 2015). It involves the sustainable development of aquaculture, fisheries, tourism, maritime transport, marine bio- technology, seabed mining, and renewable energy (World Bank and UNDESA, 2017). The conception of the blue economy emerges from the Rio +20 conference in 2012, which concentrated on sustainable development upon ocean- based economies. The earliest suggestion was proposed by Gunter Pauli 2010 in his book entitled "the blue economy: 10 years, 100 innovations, 100 million jobs" (World Bank, 2017).

Moreover, sustainable ocean-based economy might present socioeconomic advantages for present and future generations, by improving revenue generation, food security, livelihood, employment level, health status of the inhabitant, peace coexistence, and political stability (Ahmed \& Thompson, 2019).

\subsection{The Need for Blue Economy in Nigeria}

Nigeria does not have a well-developed blue economy which began globally about a decade ago. Even with traditional ocean economy which led to the establishment of the blue economy, the nation does not have reliable data (Elisha, 2019; Pérez et al., 2017). Nigerian economist have the believe that the blue economy outputs have great capacities to boost revenue generation and reduce over dependence on oil revenue (Aura et al., 2019; Elisha, 2019; Hassanali, 2020). Thus, the development of Nigerian blue economy is not only timely and complementary, but absolutely urgent and necessary.

However, to explore and optimize the blue economy potentials, Nigeria requires strong institutions, harmonized and comprehensive legal framework, for the successful implementation and effective utilization of the nation's blue economy resources. Therefore, the country has to explore and develop policies to harness its financial and environmental factors necessary for the development of its blue economy.

\subsection{Blue Economy and Revenue Generation in Nigeria}

Nigerian economy heavily depends on revenue from crude oil. Accordingly, the economy is vulnerable to the instability of the global oil prices, which presently upsetting the nation economy as the country recently entered recession due to Covid-19 pandemic.

Nevertheless, the maritime economy is becoming increasingly considerable source of improving revenue generation and prosperity to humanity (OECD, 2016). According to Peterside, (2019) "Revenue is crucial to economic development of anv nation. A rapidlv increasing population. dearth of national infrastructure. dwindling oil revenue in the face of increasing unemployment and other social economic demands all make the Blue Economy initiatives as advanced by NIMASA inevitable. Maritime professionals insist that the maritime industry has the capacity to fund Nigeria's annual 
budgets if well managed and structured to take advantage of its huge untapped resources".

However, the present operation practice of the oceans in Nigeria is based on the traditional model. Conversely, blue economy, integrates the promising sectors of marine biotechnology, profound sea mining, off-shore renewable energy and eco-tourism amongst others. These sea possessions are surrounded in the Gulf of Guinea, a major natural endowment; which means Nigeria is ignorantly seating on a blue economy with substantial opportunities to improve revenue generation for the country if perfectly harnessed. Therefore, a transformative approach must be taken to explore and actualize the blue economy as optimal option to the present and future revenue generation challenges that hinder the country's economic growth and development.

\subsection{Blue Economy and Sustainable Development}

There is growing concern on the inspiration in implementing the Blue Economy concept vis-à-vis sustainable development. For sustainable development, it implies that economic development is both comprehensive and environmentally sound, and to be performed in a way that caused no harm to natural resources and society. Therefore, the need to balance the economic, social, and environmental proportions for sustainable development is a key element of achieving blue economy (Ibrahim, 2018).

However, for sake of simplicity, table 1 draws attention to the important issues for the sustainable blue economy (WWF Baltic Ecoregion (2017, P4).

\section{Methodology}

This study used literature based research methodology to explore the initiatives for enhancing revenue generation through blue activities in Nigeria. This has become essential in order to acquire a thorough understanding of the phenomenon under study. Exploration of literature and the development of concepts is more desirable in acquiring the in depth understanding and information needed to come up with practical recommendations. As indicated by Creswell (1994), a literature based study is library based research to understand and conceptualise a social or human problem formed through the consultation and content analysis of the extant literature.

\section{Findings and Conclusions}

Potentials of the blue economy: It is clear that Nigeria has a lots of opportunities as well as potentials and resources related to potential sector of blue economy in the nation. However, analysis of the literature revealed the following issues identified from the inherent potentials in Nigeria which are:

Challenges: Therefore, the study identified the following critical issues that would affect the implementation and sustainability of the blue economy in Nigeria, these are: information and competence, Finance and investment, Compliance issues, and Lack of enabling Act and articulated policies on Blue Economy.

Policy implementation: Based on analysis of the relevant literature, it is clear that for the blue economy to be successfully actualized and properly implemented the following issues need to be addressed: Integration and coordination of ocean activities, Policy framework, Capacity development, Marine environment protection, Finance, Maritime security, Government revenue.

Integration and coordination of ocean activities: Integration and coordination are important to attain sustainable development, along with competing uses of ocean, to conserve the ecological integrity, life-supporting functions and biodiversity of the ecosystem. Fundamentally, integration is the key factor in moving forward in the Blue Economy agenda of Nigeria. The regulation and coordination of all activities surrounded by the ocean space should be critically measured as the current approach is lacking proper coordination and integration. It was also revealed that integration is the means to the coordination of other legal, institutional and implementation framework of Blue Economy, generally.

Policy framework: when the system is well integrated, the designing a comprehensive policy framework for integrating various activities for managing natural resources and the regulations of the activities become inevitable to the sustainable blue economy. These policies also consider the flora and fauna reliability and adhere to the sustainable blue economy principles, which are to appreciate the ecological, economic and the social objectives. The review revealed that the lack of a comprehensive policy framework for the implementation of the blue economy agenda or the actualization of development plans. It was also affirmed that there is no guiding policy for the propose agenda in any form.

Capacity development: Providing and managing data are crucial for policy-makers in support of measuring indicators, assessing performance, and developing policies applicable to administration of ocean resources. However, knowledge and competence are to be strengthened by relevant data quality and technology. These are essential for making relevant decisions and governance reforms which depend on important economic and scientific data that are necessary for identifying environmental costs associated with those decisions. It is equally important to note that data management is critical factor in the management of ocean and marine sectors. This is more important for Marine Spatial Planning and fisheries stock assessment data. Consequently, the current position of the nation shows inadequate data management and 
lack capacity building within the system.

Marine environment protection: Protection and conservation of the oceanic environment is essential throughout the whole implementation process of Blue Economy agenda. Though there are several considerable threats to the oceanic environment, it was identified that oil pollution was greatest threat in the Nigerian situation. Poor environmental protection act within the system seriously worsened the problem of oil spills and pollution in the oceanic environment from land-based sources.

Finance: As a result of the current pandemic (Covid-19) and recession Nigeria lacks enough financial resources strong institutions to optimize the Blue Economy potential. To this end, the major concern is about "Long- term financing mechanisms" to guarantee consistent implementation of policies and support for the clusters of industries within the Blue Economy sector. Access to finance is crucial to effectively channel the transition of established blue economy sectors.

\section{Recommendations and Policy Implementation}

Recommendations: In view of the findings and conclusions of this research, the study recommends that, all oceans related activities should be consolidated into proposed sector (blue economy) and come up with new ministry of blue economy. The study also suggested that, government should establish a comprehensive framework through a Blue Economy Act for effective management and regulation of ocean policies in the country.

The study proposed that political will and the strong institutions must be combined to effectively build knowledge and competency of employees for effective running and implementation of blue economy policies in the country in line with all existing international legal instruments.

This research suggested that, the country shall consider long-term financing mechanisms for blue economy from international sources.

Policy implementation: Although, this study is conducted with a view to be submitted to the office of AGF, however, the study identified major stakeholders that could successfully implement the proposed recommendations together with their suggested time frame. Therefore, for the first suggestion to be well implemented, that is coordination and integration of the blue economy the lawmakers need to approve the policy within one year. Similarly, for the second policy to be actualized, that is policy framework, the following stakeholders need to act on the policy within one year: NIMASA, Nigerian shippers Council, Nigerian Navy, Nigerian Port Authority, Nigerian water ways Authority, International Oil Companies, (IOCs), National Petroleum Corporation (NNPC) and ship-owners.

The study also considered the third recommendation on capacity development to be implemented by the following stakeholders: NIMASA, Nigerian shippers Council, Nigerian Port Authority, Nigerian water ways Authority, within a proposed one year time frame. For the fourth suggestion, the study considered Ministry of environment as the relevant stakeholder to implement the policy within a year.

Furthermore, for the fifth recommendation to be actualized the study considered Ministry of finance, IMF and World Bank as the bodies necessary to finance the blue economy for maximum period of five years. And also the study considered Nigerian Navy and Mobile police as the relevant security agencies to protect and secured all ocean related activities in the country within a year.

\section{Acknowledgement}

We acknowledge the support of the office of the Accountant General of the Federation of Nigeria.

\section{References}

Ahmed, N., \& Thompson, S. (2019). Science of the Total Environment The blue dimensions of aquaculture: A global synthesis. Science of the Total Environment, 652, 851-861. https://doi.org/10.1016/j.scitotenv.2018.10.163

Alongi, D. M., \& Carbon, B. (2018). The Blue Economy: Mitigation and Adaptation. Geography Compass. https://doi.org/10.1007/978-3-319-91698-9_6

Amusan, L., \& Akinyemi, T. E. (2019). Climate change, pastoral migration, resource governance and security: the Grazing Bill solution to farmer-herder conflict in Nigeria. Environmental Economics, 12. https://doi.org/10.21511/ee.08(3).2017.04

Aura, C. M., Oketch, R., Nyamweya, C. S., Njiru, J. M., Odoli, C., Musa, S., ... Okeyo, R. (2019). Using fish landing sites and markets information towards quantification of the blue economy to enhance fisheries management. Fisheries Management and Ecology, 3(2), 1-12. https://doi.org/10.1111/fme.12334

Baltic, W. W. F. E. (2017). Principles for a Sustainable blue economy. Retrieved from http://www.wwf.se/source.php/1605623/15_1471_blue_economy_6_pages_final.pdf

Cavaleri, L., Martins, M., Andrade, D., Ribeiro, M., \& Turra, A. (2020). Crafting a sustainability transition experiment 
for the brazilian blue economy. Marine Policy, 120. https://doi.org/10.1016/j.marpol.2020.104157

EC, WWF, WRI, E. (2018). The ocean is a biologically diverse and highly productive system. It is an immense source of materials, food, energy and ecosystem services.

EIU. (2015). The blue economy Growth, opportunity and a sustainable ocean economy. In The Economist Intelligence Unit Limite, 56.

Elisha, O. D. (2019). The Nigeria Blue Economy: Prospects for Economic Growth and Challenges. International Journal of Science Research in Education, 12, 680-699.

Folami, T. O. (2017). The Maritime Commons: Digital Repository of the World Maritime Towards an integrated ocean governance regime and implementation of the Sustainable Development Goal 14 in Nigeria TOWARDS AN INTEGRATED OCEAN GOVERNANCE REGIME AND IMPLEMENTATION OF THE SUST. World Maritime University.

Garland, M., Axon, S., Morrissey, J., Graziano, M., \& Heidkamp, C. P. (2019). The blue economy : Identifying geographic concepts and sensitivities. Geography Compass, 1-21. https://doi.org/10.1111/gec3.12445

Hassanali, K. (2020). CARICOM and the blue economy - Multiple understandings and their implications for global engagement. Marine Policy, 120, 104137. https://doi.org/10.1016/j.marpol.2020.104137

Ibrahim, H. D. (2018). The Maritime Commons: Digital Repository of the World Maritime Harnessing the potentials of blue economy for sustainable development of Nigeria ECONOMY FOR SUSTAINABLE DEVELOPMENT Federal Republic of Nigeria.

Katila, J., Ala-rämi, K., Repka, S., Rendon, E., \& Törrönen, J. (2019). De fi ning and quantifying the sea-based economy to support regional blue growth strategies - Case Gulf of Bothnia. Marine Policy, 100, 215-225. https://doi.org/10.1016/j.marpol.2018.11.035

OECD. (2016). The Ocean Economy in 2030. In The Ocean Economy in 2030. https://doi.org/10.1787/9789264251724en

Pérez, A., Santamaria, E. K., Operario, D., Tarkang, E. E., Zotor, F. B., Cardoso, S. R. de S. N., ... Volk, J. E. (2017). Blue Economy Vision 2025: Harnessing Business Potential for India Inc and International Partners is. BMC Public Health, 5(1), 1-8. from https://ejournal.poltektegal.ac.id/index.php/siklus/article/view/298\%0Ahttp://repositorio.unan.edu.ni/2986/1/5624. pdf\%0Ahttp://dx.doi.org/10.1016/j.jana.2015.10.005\%0Ahttp://www.biomedcentral.com/14712458/12/58\%0Ahttp://ovidsp.ovid.com/ovidweb.cgi?T=JS\&P

Voyer, M., Farmery, A. K., Kajlich, L., Vachette, A., \& Quirk, G. (2020). Assessing policy coherence and coordination in the sustainable development of a Blue Economy . A case study from Timor Leste. Ocean and Coastal Management, 192, 105187. https://doi.org/10.1016/j.ocecoaman.2020.105187

World Bank, U. nation. (2017). The Potential of the Blue Economy. In International Bank for Reconstruction and Development/The World Bank. https://doi.org/10.1596/26843

WWF. (2018). Introducting the Sustainable Blue Economy Finance Principles.

\section{Copyrights}

Copyright for this article is retained by the author(s), with first publication rights granted to the journal.

This is an open-access article distributed under the terms and conditions of the Creative Commons Attribution license which permits unrestricted use, distribution, and reproduction in any medium, provided the original work is properly cited. 